\title{
Ribosomal Protein S6 Kinase Beta-1
}

National Cancer Institute

\section{Source}

National Cancer Institute. Ribosomal Protein S6 Kinase Beta-1. NCI Thesaurus. Code C84317.

Ribosomal protein 56 kinase beta-1 ( $525 \mathrm{aa}, \sim 59 \mathrm{kDa}$ ) is encoded by the human RPS6KB1 gene. This protein is involved in phosphorylation of ribosomal protein $\mathrm{S6}$. 